\title{
NOTES
}

\section{THE IMATERIAL DISTORTION OF INCOME TEST AS APPLIED TO PREPAID INTEREST AND POINTS PAID BY PARTNERSHIPS}

When a cash-method taxpayer prepays interest or pays points on a loan, the Internal Revenue Service (Service) will examine his tax return to decide whether the deduction for payments of interest ${ }^{1}$ and points $^{2}$ in the year in which they were actually made will result in a

1. INT. REv. CODE of 1954, $\$ 163$ (a) provides, "There shall be allowed as a deduction all interest paid or accrued within the taxable year on indebtedness." The Supreme Court has stated, "In the business world 'interest on indebtedness' means compensation for the use or forbearance of money." Deputy v. du Pont, 308 U.S. 488, 498 (1940). See also Old Colony R.R. v. Commissioner, 284 U.S. 552 (1932).

Interest has been categorized as "investment interest" and "non-investment" interest. Investment interest is defined in section 163(d)(3)(D) as "interest paid or accrued on indebtedness incurred or continued to purchase or carry property held for investment." INT. REv. CODE of 1954, $\$ 163$ (d)(3)(D). There is no limit on the amount of non-investment interest which may be deducted, but the amount of investment interest deductible in any taxable year is limited. INT. REv. CODE OF 1954, $\$ 163$ (d). This distmction expresses the Congressional determination that there should be a limit on the deduction taken for interest indebtedness incurred to purchase assets which are not producing current incoine. H.R. REP. No. 13270, 91st Cong., 1st Sess. 72 (1969).

Although it is unclear at present precisely which transactions will give rise to investment interest, the term appears to be meant as a contrast to interest incurred "in connection with a trade or business" or incurred to purchase specific goods or services. $I d$. at 73. Interest paid on indebtedness incurred in the construction of property to be used in a trade or business is specifically excluded from investment interest. INT. REv. CODE OF 1954, \$163(d)(4)(D). See generally Gabmet, The Interest Deduction: Several New Installments in a Continuing Saga, 21 CASE W. REs. L. REv. 466, 486-97 (1970); Katcher, Tax-Sheltered Investments in Real Estate Under the I969 Tax Reform Act, U. So. CAL. 1971 TAX INST. 587, 617-23.

HEREINAFTER THE FOLLOWING CITATIONS WILL BE USED IN THIS NOTE:

J. Mertens, LAW of Federal Income Taxation [hereinafter cited as Mertens];

Asinow, Principle and Prepaid Interest, 16 U.C.L.A.L. Rev. 36 (1968) [hereinafter cited as Asimow];

Gabinet, The Interest Deduction: Several New Installments in a Continuing Saga, 21 CASE W. REs. L. Rev. 466 (1970) [hereinafter cited as Gabinet];

National Office, Internal Revenne Service, Memorandum to District Director, Los Angeles, California, November 17, 1972 [hereinafter cited as Memorandum].

2. In this Note, "points" refers to fees paid by the borrower to the lender as additional compensation for the use of money. One "point" is equal to one percent of the amount borrowed. See Cheeks, Has the IRS Unnecessarily Limited the Deduc- 
material distortion of his income. If a material distortion is found, the taxpayer will be required to allocate the deduction of the prepaid interest over the years in which it would otherwise have become due and apportion the deduction of points over the term of the loan. When a partnership prepays interest or pays points, the question arises as to how these deductions should be compared with income to determine whether a material distortion exists. The position recently asserted by the Internal Revenue Service is that a partnership's total prepaid interest and points deductions should be compared with the partnership's income to test for a material distortion (application of the test at the partnership level). ${ }^{3}$ In contrast, some advocates of a point of view more favorable to partnerships (for brevity, supporters of this point of view will hereinafter be referred to as "the partnerships") have argued that each partner's share of the partnership's prepaid imterest and points deductions should be compared with that partner's income to test for a material distortion (application of the test at the partner level). ${ }^{4}$ It has been assumed by both sides that if prepaid interest and points are separated from other items of partnership income so that they retain their character on the partners' individual returns, the material distortion test must be applied at the partner level. ${ }^{5}$ On the other hand, it has been further assumed that if prepaid interest and points are not so separated, the test inust be applied at the partnership level. ${ }^{\circ}$ Acting on these assumptions, the parties have joined issue on whether prepaid interest and points are required by the Code to be separated so that they retain their character on the partners' returns.

This Note will suggest that these related assumptions, which underlie both positions, are erroneous, and that they have led the parties to a faulty analysis of the problem. In developing this conclusion, this Note will first review the way in which the material distortion of income test has been applied to prepaid interest and points and the way in which items of partnership income are attributed to partners by the Code. Next, the arguments made by the Service and the partnerships

tion for Mortgage "Points"? $31 \mathrm{~J}$. TAx. 290, 292 (1969). In order to be deductible as interest, points must be paid solely for the use of money and not for specific services performed by the lender such as investigative charges or closing costs. Rev. Rul. 188, 1969-1 CuM. Bull. 54, 55. For example, points paid for VA and FHA loans are considered service charges and are not deductible as interest. Rev. Rul. 650, 1968-2 Cum. Bull. 78; Rev. Rul. 297, 1967-2 Cum. Bull. 87. See also 5 CCH Fed. TaX Rep. II 4430.0203 (1973).

3. See Memorandum 7, 8 .

4. See id. 7.

5. See id. 6.

6. See id. 8. 
concerning the proper application of the material distortion of income test with respect to prepaid interest and points paid by a partnership will be set forth and examined. Finally, after criticizing both of these arguments, this Note will set forth an alternative analysis and solution of the problem which results in the application of the material distortion of income test at the partnership level in all cases.

\section{Prepati Interest, Points, and Material Distortion OF INCOME-GenERAL CONSIDERATIONS}

For inany years, taxpayers using the casls method of accounting have been allowed, subject to certain limitations, ${ }^{7}$ to deduct prepaid interest in the year in which it was actually paid rather than $m$ the year in which it would otherwise lrave beconne due. ${ }^{8}$ One advantage of prepaying interest is that, by doing so, a taxpayer is able to "time" his interest deduction. ${ }^{9}$ By electing to prepay interest in a year in which his income is unusually high, he can shelter some of his otherwise highbracket income. Prepayinent of interest nay also be advantageous in the context of speculative land purchases, for it can enable the taxpayer to use largely tax-deductible dollars to finance his investment. ${ }^{10} \mathrm{He}$

7. Prior to 1968 , a taxpayer could deduct up to and including five years' prepaid interest if the underlying transaction was neither a sham nor without some business purpose beyond the tax consequences. See, e.g., Knetsch v. United States, 364 U.S. 361 (1960); Bridges v. Commissioner, 325 F.2d 180 (4th Cir. 1963). See generally Asimow, 37-41; Dworkin, Interest Paid and Received-Attractive Alternatives for Taxpayers, 41 TAXEs 614, 629-30 (1963); Gabinet 467-72; Kanter, The Interest Deduction: When and How Does It Work, N.Y.U. 26TH INST. on FeD. TAX. 87 (1968); Webster, Prepaid Interest-Tax and Local Law Considerations for the Payor and Payee, U. So. CAL. 1967 TAX INST. 381, 385-92, 399-421.

Further limitations were imposed by the enactment in 1968 of Revenue Ruling 68-643, 1968-2 Cum. Butc. 76. For a discussion of Revenue Ruling 68-643, see notes 22-29 infra and accompanying text.

8. Although the total amount of the deduction is the same whether or not interest is prepaid, prepayment has significant tax advantages. See text accompanying notes 9-10 infra. A detailed discussion of the many ways in which prepaid interest can be used as a tax advantage is beyond the scope of this Note. Indeed, the "variations in the type and terms of prepaid interest deals are myriad." Kaster, Prepaid Interest Purchase Method Still Useful Despite IRS Attack, 30 J. TAx. 16, 21 (1969). Many of the ways in which prepaid interest can be used advantageously have, however, been discussed elsewhere. See Asinow 37-41; Dworkin, supra note 7, at 614, 629-30; Kanter, Interest Deduction: Use, Ruse, Refuse, 46 TAXES 794, 813-14 (1968); Kaster, supra; Roulac, Financing Ideas: The Economics of Prepaid Interest, 2 REAL EsTate L.J. 598 (1973); Comment, Prepaid Interest-Gimmickry and an Answer, 56 CALIF. L. REv. 1250, 1258-61 (1968); Use of Foundation to Cut Interest Income, 28 J. TAx 62 (1968).

9. See Asinow 40; Kanter, supra note 8, at 798-99.

10. See Asimow 41; Dworkin, supra note 7, at 629-30; Kanter, supra note 8, at 813-14; Roulac, supra note 8, at 598. 
may do this by taking out a large loan secured by the land to be purchased and arranging to have the initial installments consist largely of prepayments of interest rather than repayment of principal. By deducting this interest, the taxpayer is able to finance his purchase largely with tax-deductible dollars, thereby reducing his after-tax outlay. Thus, the cost of speculation can be reduced considerably; and, if the taxpayer is not personally liable on the loan, the risk taken is minimal.

\section{Material Distortion of Income by Prepayment of Interest}

Although the use of the prepaid interest deduction has been subjected to certain limitations, these limitations have been insufficient to curb abuses of the deduction. In order to prevent further use of the prepaid interest deduction as a tax avoidance mechanism, the Service has applied the inaterial distortion of incoine test. The material distortion of income test arises out of section 446 of the Internal Revenue Code. Subsection $446(a)^{11}$ allows a taxpayer to use the accounting method of his choice. Most taxpayers choose either the cash inethod ${ }^{12}$ or the accrual method. ${ }^{13}$ Subsection $446(b),{ }^{14}$ however, imposes

11. INT. Rev. CODE OF 1954, $\$ 446$ (a) provides: "Taxable income shall be computed under the method of accounting on the basis of which the taxpayer regularly computes his income in keeping his books."

A method of accounting will be acceptable if it (1) is consistently followed by the taxpayer and (2) clearly reflects his income. Huntington Sec. Corp. v. Busey, 112 F.2d 368, 370 (6th Cir. 1940); 2 MERTENS $\$ 12.05$ (1967 revision).

12. Treas. Reg. $\$ 1.446-1$ (c) (i) (1957) explains the cash method as follows:

Generally, under the cash receipts and disbursements method in the computation of taxable income, all items which constitute gross income (whether in the form of cash, property or service) are to be included for the taxable year in which actually or constructively received. Expenditures are to be deducted for the taxable year in which actually made.

Expenditures by a cash-method taxpayer for interest payments are deductible in the year actually paid. Clinton H. Mitchell, 42 T.C. 953, 969 (1964). For a comprehensive discussion of the cash method of accounting, see 2 MERTENS $\$ \$ 12.38-.59$ (1967 revision).

13. Treas. Reg. $\$ 1.446-1$ (c)(ii) (1957) explains the accrual method as follows:

Generally under an accrual method, income is to be included for the taxable year when all the events have occurred which fix the right to receive such income and the amouut thereof can be determined with reasonable accuracy. Under such a method, deductions are allowable for the taxable year in which all the events have occurred which establish the fact of the liability giving rise to such deduction and the amount thereof can be determined with reasonable accuracy.

Expenditures by an accrual-method taxpayer for interest payments are deductible in the year in which the interest accrued. Guantanamo \& W.R.R., 31 T.C. 842, 852 (1959). For a comprehensive discussion of the accrual method of accounting, see 2 MERTENS $\$ \S 12.60-.94$ (1967 revision).

14. INT. REv. CODE OF 1954, $\$ 446$ (b) provides:

If no method of accounting has been regularly used by the taxpayer, or if the method used does not clearly reflect income, the computation of taxable income shall be made under such method as, in the opinion of the Secretary 
certain limitations on the taxpayer's ability to choose his own accounting inethod. It gives the Commissioner the power to require that a taxpayer use an accounting method other than the one he has chosen if, in the Commissioner's opinion, the taxpayer's choice of method does not clearly reflect (that is, materially distorts) his income.

The Internal Revenue Service applied the material distortion of income concept to the prepayment of interest through Revenue Ruling 68-643.15 This Ruling states:

A deduction for interest paid in advance on each indebtedness for a period not in excess of 12 months of the taxable year immediately following the taxable year in which the prepayment is made will be considered on a case by case basis to determine whether a material distortion of income has resulted. . . . If interest is prepaid for a period extending more than 12 months beyond the end of the current taxable year, the deduction of such prepaid interest in the taxable year of payment will be considered as materially distorting incoine. Where a material distortion of income has been found to result from the deduction of prepaid interest, the Service will require the taxpayer to change his method of accounting with respect to such prepaid interest in order to allocate it over the taxable years involved. ${ }^{16}$

Thus, deductions for prepayments of interest extending more than one year past the current taxable year will be considered to have materially distorted income and will be autonatically prorated. Other deductions for prepayments of interest will be examined on a case-by-case basis, using factors set out in the Ruling to determine whether a 1naterial distortion of income has resulted. The factors which bear on whether there has been a material distortion of incoine include:

(1) the amount of incoine in the taxable year of payment,

(2) the income of previous taxable years,

(3) the amount of prepaid interest,

(4) the time of payment,

(5) the reason for payment, and

(6) the existence of a varying rate of interest over the term of the loan. ${ }^{17}$

Although the manner of applying these factors and the relative weight

or his delegate, does clearly reflect income.

See generally 2 MERTENS $\$ 12.05$ (1967 revision).

15. 1968-2 Cum. BuLL. 76. For differing opinions on the validity and advisability of Revenue Ruling 68-643, compare Asimow with Bauman, Prepaid Interest-Where Have All the Deductions Gone? 55 A.B.A.J. 1091, 1093 (1969) and Gabinet 466-86.

16. 1968-2 CUM. BULL. 76, 77.

17. $1 d$. 
they will be accorded in determining whether a material distortion has occurred have not yet been made clear by the Service, the factors theinselves suggest that the Service will find a material distortion of income unless the prepayment is small in comparison to total income and similar items of prepaid interest regularly appear on the taxpayer's return. ${ }^{18}$ If a material distortion of income is found to exist, the Service will require the cash-method taxpayer to capitalize the prepaid interest and deduct it as it accrues, forcing him to take his deduction at the time when the payment would have been earned by the lender. A1though Revenue Ruling 68-643 speaks only of prepaid interest, Revenue Ruling $69-188^{10}$ has expanded the concept of interest to include points paid to a lender solely for the "use or forbearance of money."20 As a result, the Service has decided that Revenue Ruling 68-643 should also be applied to points. ${ }^{21}$

Although the question of whether the material distortion of income test should be applied at the partnership or partner level is at the heart of the current problem, the first step in the analysis should be an examination of Revenue Ruling 68-643, which forms the foundation upon which the problein has arisen. The Commissioner's decision in Revenue Ruling 68-643 came as somewhat of a surprise to the $\operatorname{tax}$ bar, $^{22}$ and it has been a subject of dispute among legal scholars. ${ }^{23}$ Briefly, this dispute centers on whether or not the decision of the Commissioner to require the use of the accrual method of accounting with respect to prepayments of interest for a period of more than one year beyond the end of the current taxable year is a permissible exercise of his discretion. One commentator has argued that the legislative history of section $446(\mathrm{~b})$ and the case law on the subject indicate that

18. Because the ruling fails to indicate how to apply the material distortion factors listed and because the enumerated factors are only soine of the factors that will be applied by the IRS, the prepaid interest route is now a complete gamble from the planning standpoint. Bauman, supra note 15 , at 1023.

It would seem, however, that factors (1), (2), and (3) taken together indicate that the Commissioner will find a material distortion of income when a significant amount of prepaid interest is deducted in a year in which the taxpayer's income is unusually high. Factors (3), (4), and (5) taken together indicate that a small prepayinent made routinely every year will not be considered as distorting incone. Presunnably factor (4) is meant to prevent a taxpayer from bunching his prepayments at the end of a particularly high-income taxable year. For differing views on how the factors may be applied, see Asimow 37 n.2; Bauman, supra; Kaster, supra note 8, at $18-19$.

19. 1969-1 Cum. BulL. 54. For an in-depth discussion of the practical significance of the Ruling, see Cheeks, supra note 2.

20. Rev. Rul. 188, 1969-1 CuM. Bull. 54.

21. Meinorandum 8.

22. See, e.g., Dworkin, supra note 7, at 630; Webster, supra note 7, at 431-32.

23. Compare Asinow with Gabinet 466-86. 
it is within the Commissioner's discretion to order changes in the method of accounting in such circumstances. ${ }^{24}$ On the other side, it has been contended that, although the legislative history and case law support a finding that the Commissioner has the discretion to require changes of accounting method after review on a case-by-case basis, it is an abuse of discretion to require an automatic change of accounting method in every case in which a cash method taxpayer has prepaid interest for a period of more than one year beyond the end of the current taxable year. ${ }^{25}$ This dispute is, however, of limited importance to the problem at hand; even if the courts were to prohibit the Commissioner from automatically allocating the deduction of prepaid interest and points over the applicable years whenever the prepayment has been made for a period of more than one year beyond the end of the current taxable year, the Commissioner then would surely extend his case-by-case review to cover all cases of prepaid interest. It could then be expected that the Commissioner would find a material distortion of income requiring the allocation of the interest deduction in almost every case to which the automatic allocation provision previously would have applied. Since the Commissioner lias broad power to determine whether a taxpayer's accounting method clearly reflects his income, ${ }^{20}$ the replacement of the automatic allocation provision by a policy of systematic case-by-case review would be of limited utility to taxpayers seeking to take advantage of the favorable tax consequences resulting from the prepayment of interest. This result, in essence, would merely allow the taxpayers the opportunity to litigate an issue on which they probably would have only a slight clrance of success. ${ }^{27}$

Although not relied on by the Service in Revenue Ruling 68-643, two additional theories for requiring the allocation of the prepaid interest deduction over the period of the loan have also been postulatedthe "capitalization" theory and the "deposit" theory. The "capitalization" theory would require that prepaid interest be viewed as a capital expenditure for an intangible asset which ought to be amortized over

24. Asimow 49-58. Although a detailed analysis of this argument is beyond the scope of this Note, Professor Asimow develops his argument clearly and in detail. Id.

25. Gabmet 472-77. See also Bauman, supra note 15 . A detailed analysis of this argument is beyond the scope of this Note, but it has been ably set out by the commentators cited.

26. "The Commissioner has broad powers in determining whether accounting methods used by a taxpayer clearly reflect income . ..." (citation ounitted). Commissioner v. Hensen, 360 U.S. 446, 467 (1959). See also 2 Mertens $\$ 12.14$ (1967 revision); Asimow 51 n.71.

27. But cf. Kaster, supra note 8, at 18-19, 21. 
the years to which the prepayment is attributable. ${ }^{28}$ Accordingly, the interest deduction would be spread over the period of the loan. Under the "deposit" theory, prepaid interest would be treated merely as a refundable deposit for which no deduction could be taken until the year im which the interest is earned by the lender. ${ }^{29}$ At that time, the payment would become non-refundable and the deduction could be taken. If the courts were to accept either of these theories, the dispute as to whether the material distortion test with respect to prepaid interest should be applied at the partnership or partner level would be stripped of its vitality. In either case all prepayments of interest would be required to be allocated over the life of the loan without regard to the material distortion of income test.

\section{Material Distortion of Income by Payment of Points}

Although Revenue Ruling 68-643 appears to be a reasonable response to certain abuses of the deduction of prepaid interest, the Service's position that the payment of points should be treated in the saine manner as prepaid interest is of questionable validity and is more vulnerable to attack. ${ }^{30}$ The Service's position is apparently the result of a rather mechanical application of Revenue Ruling 68-643 to Revenue Ruling 69-18811 (whicli holds that points are to be considered as imterest). The Service's position is liard to justify, however, since the considerations which support the result reaclied by Revenue Ruling 68-643 relating to prepaid interest do not apply with equal force to the payment of points. First, by their very nature, points are payable at the time when a loan is taken out..$^{32}$ The taxpayer paying points is less able than is the taxpayer prepaying interest to "time" the payment in order to shelter high-bracket income. He can only control the timing of the deduction by choosing the year in which to take out the loan. The taxpayer prepaying interest, however, can take out the loan at any time with the provision that lie inay prepay interest at some time

28. Compare Asimow 58-68 with Gabinet 477-84.

29. If the loan is repaid before the prepaid interest has been earned, the unearned portion will be refunded. Hence, the prepaid interest is likened to a refundable "deposit." Compare Asimow 69-74 with Gabinet 484-86.

30. Indeed, there has been some indication that the Service itself is uncomfortable with this position. In one case the Service concluded that the payment of $\$ 1,200$ (six points) on a $\$ 20,000$ mortgage loan was deductible in the year of payment. Rev. Rul. 582, 1969-2 CuM. BuLL. 29. It has been suggested that this Ruling may foreshadow a number of such rulings which would minimize the effect of Revenue Ruling 68-643 on points payments. Gabinet 476 .

31. 1969-1 CuM. BuLL. 54. See notes 19-21 supra and accompanying text.

32. Cheeks, supra note 2, at 292. 
in the future when it would be most advantageous to him. Second, since points fit the criteria for immediate deductibility under either the cash or the accrual inethod of accounting, ${ }^{33}$ the payment of points by a borrower is not a case in which he has atteinpted to decrease his tax liability by his choice of accounting method. In light of this fact, the language in Revenue Ruling 68-643 that, in the event a material distortion is found, "the Service will require the taxpayer to change his method of accounting with respect to such prepaid interest"34 is a strong indication that the Ruling was not meant to apply to the payinent of points. Indeed, a change of accounting method would not alter the time at which the points should be deducted. Third, in contrast to prepaid interest, which is refundable in the event that the loan is repaid before the year in which the interest which was prepaid would have become due, points are not refundable. ${ }^{35}$ For these three reasons, points are not very useful as a tax avoidance device, and taxpayers usually would rather pay the increased cost of a loan through a higher interest rate. ${ }^{36}$

Although it seems that Revenue Ruling 68-643 should not be apphed to the payment of points, the proposed "capitalization" theory, ${ }^{37}$ which would require that the deduction for prepaid interest be allocated over the period of prepayment, is equally applicable to the payment of points. This conclusion is based on the notion that points are a cost of obtaining an asset having a useful life, and, therefore, any deduction of points should be taken ratably over the life of the loan. Since valid considerations support the application of Revenue Ruling 68-643 to prepaid interest, the "capitalization" argument would be more likely to appear in relation to the points deduction.

\section{Prepaid Interest, Points, and Material Distortion OF INCOME-PARTNERSHTP ASPECTS}

Despite the limitation imposed by Revenue Ruling 68-643 on the

33. Because points are expenditures made in the current taxable year, they are "to be deducted for the taxable year in which actually made". under the cash mcthod. Treas. Reg. 1.446-1(c)(i) (1957). See note 12 supra. Since all the "events have occurred which establish the fact of liability" and "the amount thereof can be determined with reasonable accuracy" in the taxable year of payment, an accrual-method taxpayer must also deduct points in the year of payment. Treas. Reg. $\S 1.446-1$ (c) (ii) (1957). See note 13 supra.

34. Rev. Rul. 643, 1968-2 Cum. Bull. 76, 77.

35. Because points are not refundable, the "deposit" theory, see note 29 supra and accompanying text, is not applicable to points payments.

36. Cheeks, supra note 2, at 291.

37. See note 28 supra and accompanying text. 
deductibility of prepaid interest, the prepaid interest shelter has retained importance, especially with respect to large loans taken out by partnerships in order to finance large real estate transactions. ${ }^{38} \mathrm{Re}-$ cently, the Internal Revenue Service has adopted a position which, in addition to Revenue Ruling 68-643, would further diminish the usefulness of the prepaid interest shelter for partnerships. ${ }^{39}$ Heretofore the material distortion test has uniformly been applied at the partner level. ${ }^{40}$ The Service now contends, however, that in most cases the material distortion of income test, as it relates to prepaid interest and points paid by cash-method partnerships, should be applied at the partnership level rather than at the partner level. ${ }^{41}$ The Service would allow the application of the material distortion test at the partner level only if the partnership could affirmatively show that the application of the test at the partner level would result in a tax hability for some partner different from the tax liability which would result from the application of the test at the partnership level. ${ }^{42}$

To the extent that the Service's approach requires the material distortion test to be applied at the partnership level rather than at the partner level, it will be disadvantageous to partnerships which are using prepaid interest to shelter incoine. This follows from the fact that if the material distortion test is applied at the partnership level, there would generally be a clear distortion of the partnership income since a large deduction for interest and points is usually used to offset a small amount of income to produce a sizeable deductible loss for the taxable year. ${ }^{43}$ A finding of a material distortion of income at the partnership level would force the partnership to allocate the deduction of prepaid interest over the years in which it becomes due and the deduction of points over the term of the loan. This would, in effect, force every

38. For a discussion of the advantages of financing real estate transactions largely through the use of loans, see A. AXelrod, C. Berger \& Q. Johnstone, Land Transfer and Finance 103-06 (1971); Hall, Tax Leveraging, U. So. CaL. 1970 TAX INST., 299, 307-09; Katcher, supra note 1, at 617-23. For an example of how the limited partnership is used as a tax shelter in real estate, see 1 S. SuRreX, W. WARREN, P. MCDanieL \& H. AUlt, Federai InCOME TAXation 421-36 (1972).

39. See Memorandum 7, 8.

40. Roulac, supra note 8, at 599.

41. See Memorandum 7, 8.

42. Id. 7. This requirement that the partnership make an affirmative showing is discussed in the text following note 67 infra.

43. See Memorandum 8; Roulac, supra note 8, at 599. Partnerships which use prepaid interest as a tax-avoidance device are generally involved in a single project. In the early years of the project, before any significant incoine is being generated, a large deduction for prepaid interest produces a loss which the partners use to shelter their high-bracket income. 
partner to do the same with respect to his share of the partnership's deduction. On the other hand, if the material distortion test were applied at the partner level, each partner's return would be examined separately for a material distortion of income caused by the immediate deduction of his share of the partnership's points and prepaid interest. Although some partners might be required to allocate these deductions over a number of years, because to do otherwise would materially distort their incomes, other partners whose imcomes were not similarly distorted would be allowed to take the full deduction in the year of actual payment. ${ }^{44}$

\section{Partnership Income and Partners}

In order better to understand and assess the positions of the Service and the partnerships, it will be helpful to review the way in which partnership income and losses are treated for tax purposes by the Internal Revenue Code. Sections 701 through 703 are the basic provisions for determining the manner in which partnership incone and deductions are to be attributed to the partners. Section $701^{45}$ provides that the partnership itself is not a taxable entity and that the partnership's incoine is attributed to the partners for tax purposes. The partners thus become liable in their individual capacities for the tax upon their distributive shares ${ }^{46}$ of the partnership's income, and the partnership inust only file an information return. ${ }^{47}$ However, subsection 703(b) states that the partnership must make "[a]ny election

44. Roulac, supra note 8 , at 599 . On the other hand, application of the material distortion test at the partner level might also be disadvantageous for some partners. If a partner has substantial personal prepaid interest, it would have to be added to his share of the partnership's prepaid interest, and the total prepaid interest would then be compared with his income to determine whether a material distortion would be caused by the immediate deduction of the prepaid interest. See notes 54-56 infra and accompanying text. The partner might then be required to allocate his prepaid interest deduction. If application of the test at the partnership level would not have resulted in the finding of a naterial distortion, applicatiou of the test at the partner level would thus be disadvantageous for that partner. However, this coinbination of circumstances would probably be unusual, and application of the test at the partner level will usually be advantageous for the partners.

45. INT. REv. CODE OF 1954, \& 701 provides: "A partnership as such shall not be subject to the income tax imposed by this chapter. Persons carrying on business as partners shall be hable for income tax only in their separate or individual capacities." See generally 6 MERTENS $\$ 35.01$ (1968 revision).

46. INT. REv. CODE of $1954, \S 704$ sets out the procedure for the determination of each partner's distributive share. See generally 6 MERTENs $\& 35.29$ (1968 revision); Jackson, Johnson, Surrey, Tenen \& Warren, The Internal Revenue Code of 1954: Partnerships, 54 COLUM. L. REv. 1183, 1187-94 (1954).

47. INT. REV. CODE OF 1954, § 6031. 
affecting the computation of taxable income derived from a partnership . . .."48 Thus, although the partners are individually liable for the tax on the partnership's income, elections inade by the partnership under subsection 703(b) are binding on the individual partners.

In reporting its incoine on the information return, the partnership must divide and report its income, gains, losses, deductions, and credits into the nine categories set forth in paragraphs (1) through (9) of subsection 702(a). ${ }^{49}$ When a partner reports his distributive share of the partnership's income on his individual return, subsection 702(b) ${ }^{50}$ requires that the character of any item of partnership incoine, gain, loss, deduction, or credit listed in paragraphs 702(a)(1) through (8) is to "be determined as if such item were realized directly from the source from which realized by the partnership . . . ."51 Accordingly, each partner's share of the itens separated under paragraphs 702(a) (1) through (8) will be treated on the partner's return as if the partner had personally realized the incoine, gain, loss, deduction, or credit in precisely the same manner in which it was realized by the partnership. ${ }^{52}$

48. Id. § 703(b).

49. INT. REV. CODE OF 1954, § 702(a) provides:

SEC. 702. INCOME AND CREDITS OF PARTNER.

(a) GENERAL RUIE-In determining his income tax, each partner shall take into account separately his distributive share of the partnership's-

(1) gains and losses from sales or exchanges of capital assets held for not more than 6 months,

(2) gains and losses from sales or exchanges of capital assets held for more than 6 months,

(3) gains and losses from sales or exchanges of property described in section 1231 (relating to certain property used in a trade or business and involuntary conversions),

(4) charitable contributions (as defined in section 170(c) ),

(5) dividends with respect to which there is provided an exclusion under section 116, or a deduction under part vill of subchapter $B$,

(6) taxes, described in section 901, paid or accrued to foreign countries and to possessions of the United States,

(7) partially tax-exempt interest on obhigations of the United States or on obligatious of mstrumentalities of the United States as described in section 35 or section 242 (but, if the partnership elects to amortize the premiums on bonds as provided in section 171, the amount received on such obligations shall be reduced by the reduction provided under section 171(a) (3) ),

(8) other items of income, gain, loss, deduction, or credit, to the extent provided by regulations prescribed by the Secretary or his delegate, and

(9) taxable income or loss, exclusive of items requiring separate coinputation under other paragraphs of this subsection.

50. INT. REV. CODE OF 1954, § 702(b) provides:

The character of any item of income, gain, loss, deduction, or credit included in a partner's distributive share under paragraphs (1) through (8) of subsection (a) shall be determined as if such item were realized directly from the source from which realized by the partnership, or incurred in the same manner as incurred by the partnership.

51. Id.

52. Treas. Reg. $\S 1.702-1$ (b) (1956). This provision corrected a defect in the 1939 Code under which it was unclear whether or not a partner would have to aggregate his personal gains and losses from items such as gambling losses and charitable 
In order to prevent double deduction of items which are required to be separated under paragraphs 702(a)(1) through (8), such items may not be deducted from the partnership's income at the partnership level. ${ }^{53}$ In determining the amount allowable to each partner of any deduction or exclusion as to which the Code imposes a limitation, and which is required to be separated under paragraphs 702(a)(1) through (8), each partner must aggregate his personal deductions or exclusions with his distributive share of the partnership's deductions or exclusions to determine his total deduction or exclusion. ${ }^{54}$ For example, a partner's distributive share of the partnership's charitable contributions ${ }^{55}$ will be aggregated with the partner's personal charitable contributions for purposes of determining that partner's total contributions to charity for the taxable year. ${ }^{56}$ In contrast, items of income or loss not required to be separated under paragraphs 702(a)(1) through (8) will be lumped together under paragraph 702(a)(9), ${ }^{57}$ and their special character, if any, will not be passed on to the partners. Items which are reported separately under paragraphs 702(a)(1) through (8) so that they retain their special character on the partners' returns are referred to as separated items; and items which are reported under paragraph 702(a)(9) so that they do not retaim their character on the partners' returns are referred to as nonseparated items.

Paragraph 702(a)(8) ${ }^{68}$ allows the Commissioner to require by regulation the separation of any other item of income, gain, loss, de-

contributions with his distributive share of the same items. - See Jackson, Jolinson, Surrey, Tenen \& Warren, supra note 46, at 1185-86.

53. INT. REv. CODE OF 1954 \& 703(a)(2) provides in pertinent part:

The taxable income of a partnership shall be computed in the same manner as in the case of an individual except that the following deduction shall not be allowed to the partnership: ... (C) the deductions for taxes provided in section 164(a) with respect to taxes, described in section 901, paid or accrued to foreign countries and to possessions of the United States, (D) the deduction for charitable contributions provided in section 170 .....

If the partnership were allowed to deduct froin its taxable income items which were also separated and passed on to the partners, the partners would, in effect, have a double deduction for such items. Of the items required to be separated under subsection 703(a), paragraph 703(a)(2) ouly specifically lists foreign income taxes and charitable contributions. However, the argument against double deduction applies equally to all separated items so the partnership would be denied a deduction for any separated itenı. MERTENs, CODE COMMENTARY $\$ 703$ n.2.

54. Treas. Reg. \& 1.702-1(a)(8)(iii) (1956).

55. See note 49 supra.

56. INT. REv. CODE OF 1954, $\$ 170$ (b) limits the amount of charitable contributions which may be deducted by a taxpayer in a taxable year. It is the partner's total charitable contribution (the sum of his personal plus his distributive share) which is subject to the limitation of subsection 170 (b).

57. See note 49 supra.

58. Id. 
duction, or credit not specifically designated in paragraphs 702(a)(1) through (7) so that its special character will be passed on to the partners. ${ }^{59}$ In order to specify when other items of income must be separated, the Internal Revenue Service has issued Treasury Regulations $1.702-1$ (a) (8) (i) ${ }^{60}$ and 1.702-1 (a) (8) (ii). ${ }^{61}$ Regulation 1.702-1 (a) (8) (i) requires that certain specific items be separated. Regulation 1.702-1 (a) (8) (ii) provides for the separation of other items when certain conditions are met, but not otherwise. It states:

Each partner inust also take into account separately his distributive share of any partnership item which if separately taken into account by any partner would result in an income tax liability for that partner different from that which would result if that partner did not take that item into account separately. ${ }^{62}$

The proper interpretation of this Regulation has been regarded by both the Internal Revenue Service and by those opposed to applying the material distortion test at the partnership level as being of primary inportance in resolving the problem of whether the material distortion of incoine test with respect to prepaid interest and points is to be applied at the partnership or partner level.

\section{Material Distortion and Partnerships-Application of the Test at the Partnership OR Partner Level?}

If prepaid interest and points are not separated under paragrapl 702(a)(8), the material distortion test nust be applied at the partnership level. This is because each partner's distributive share of the deduction for prepaid interest and poimts would then be reported under paragraph 702(a) (9) with other nonseparated income and deductions and would not be reflected on the partner's return in a way permitting the application of the test. Since the application of the test at the partner level would then be impossible, the test would have to be applied at the partnership level. If, on the other hand, prepaid interest and points are separated, it has been assumed by both the Service and the partnerships that the material distortion test must be applied at the individual partner level. ${ }^{63}$ This assumption is apparently based on the fact that

59. Investment interest is an example of one such item required to be separated. INT. REv. CODE of 1954, § 163(d)(4)(B). The term "investment interest" is discussed in note 1 supra.

60. Treas. Reg. $\$ 1.702-1$ (a)(8)(i) (1956). This Regulation contains a list of certaim items which must be separated.

61. Treas. Reg. $\$ 1.702-1(a)(8)$ (ii) (1956).

62. Id. (emphasis added).

63. See Memorandum 6-8. 
items required to be separated are not deducted from the partnership's incoine but are passed down to the partners and deducted at that point. By inaking this assumption, the Service and the partnerships have reduced the problem to a dispute over whether prepaid interest and points should be separated so that they retain their characters on the partners' returns. ${ }^{64}$ It is submitted that this underlying assumption is unwarranted and that it leads to a faulty analysis of the problem.

\section{The Internal Revenue Service's Approach-Application of the Test to Partnerships}

The position taken by the Service regarding the application of the material distortion test with respect to prepaid interest and points paid by a partnership is as follows. ${ }^{65}$ Since separation of prepaid interest is not provided for under paragraphs (1) through (7) of subsection 702(a), prepaid interest can only be separated if a regulation promulgated under paragraph 702 (a) (8) so requires. Although prepaid interest is not required to be separated under Regulation 1.7021 (a) (8) (i), it may qualify for separation under Regulation 1.7021(a) (8) (ii). An item qualifies for separation under Regulation 1.702-1(a) (8) (ii), the Service contends, if a showing is made that separation would in fact produce a tax hability for some partner different from that which would be produced by lonseparation. The partnership could make this showing by demonstrating that application of the material distortion test at the partnership level (nonseparation) would result in allocation of the deduction by the partnership, whereas application of the test at the partner level (separation) would not require every partner to allocate his share of the deduction. ${ }^{68}$ Thus, the

64. See Id.

65. Id. 5-8.

66. A showing that application of the material distortion test at the partnership level (nonseparation) would not result in allocation of the deduction for the partnership, whereas application of the test at the partner level (separation) would result in allocation of the distributive share of the deduction for some partner would also lead to the conclusion that separation would produce a tax liability for some partner different from nonseparation. However, this showing would never be made by the partnership because, if it could be shown that no material distortion would be found at the partnership level, the partnership would be content to allow the application of the test at that level.

Even if only one partner's tax liability were affected differently by separation, prepaid interest and points would have to be separated for all partners. Treas. Reg. $\$ 1.702-1(\mathrm{a})(8)$ (ii) (1956); see note 62 supra and accompanying quotation. Thus, it is not a permissible result under the Code that prepaid interest and points be allocated only for those partners whose incone is materially distorted by the total deduction in the year of payment. 
Service concludes that the material distortion test with respect to prepaid interest must be applied at the partnership level unless the partnership involved can affirmatively make that showing. Since Revenue Ruling 69-188 lolds that points are to be considered interest, the Service has applied the same analysis to points payments. ${ }^{67}$

Since it is not yet clear how the factors set out in Revenue Ruling 68-643 for determining whether a material distortion of income las been caused by the deduction of prepaid interest and points in the year of payment will be applied in specific situations, the weight of the burden placed on the partnership in making the requisite affirmative showing is uncertain. Even if the material distortion test is applied at the partner level, a partner could not deduct the prepaid interest and points in the year of payment unless the deduction did not materially distort his income. The same combination of factors which would result in a finding that such deductions did not materially distort a partner's income would also enable a partnership to satisfy the affirmative showing required by the Service. Since the consequence of applying the inaterial distortion test at the partnership level-that every partner would be required to allocate the deductions-will only obtain under the Internal Revenue Service's position if no partner can slow that his imcome would not be materially distorted under separation, in which event all partners would be required to allocate the deduction anyway, it seems that the only practical effect of the IRS position is to shift to the taxpaying partners the burden of proof with respect to material distortion. Even so, the partnerships have strongly disputed the Service's position. Simce the analysis of the problem suggested by this Note would result in the application of the material distortion test with respect to prepaid interest and points at the partnership level in every case, perhaps the partnerships have tried to keep the Service's attention focused on the issue of whether prepaid imterest and points must be separated so that it would not address the more basic issue.

\section{The Partnership's Approach-Application of the Test to Partners}

The main thrust of the partnerships' attack has been that the would in Regulation 1.702-1(a) (8) (ii) should be interpreted to mean "would possibly" or "could." 68 The partnerships contend that, if the "would" language of the Regulation is imterpreted to mean "could," prepaid interest and poimts would always have to be separated under paragraph 702(a)(8) because there is always the possibility that sepa-

67. Memorandum 8.

68. Id. 7 . 
ration could produce a different tax liability from nonseparation for some partner, regardless of whether it would actually do so. ${ }^{60}$ Where prepaid interest and points are not separated and the application of the material distortion test at the partnership level causes the deduction of prepaid interest and points to be allocated over the applicable years, each partner is, in effect, required to allocate over the same years his distributive share of the deduction for the prepaid interest and points. If, however, the prepaid interest and points are separated under paragraph 702(a)(8) and the material distortion test is applied at the partner level, there would be the possibility that some partners would not be required to allocate the deduction. Thus, it is argued that separation of prepaid interest and points could produce a different tax liability from nonseparation for some partner. Under the "could" interpretation of Regulation 1.702-1(a)(8)(ii), the fact that this possibility exists mandates the separation of prepaid interest and points in every case and the subsequent application of the material distortion test with respect to these two items at the partner level.

Two bases have been asserted to support the partnerships" "could" interpretation. The first basis is found in the legislative history of paragraph 702 (a)(8), where the Senate Report states:

Paragraph (8) is a "catch-all" provision which authorizes the Secretary or his delegate to prescribe regulations to require each partner to take into account separately his distributive share of any other items of income, gain, loss, deduction, or credit, the character of which would affect the computation of the partner's personal income tax. For exauple, partnership gain or loss from gambling operations may be required to be segregated in order to permit individual partners to offset personal gambling gains and losses against their shares of such gams and losses realized by the partnership..$^{70}$

The second basis for the "could" interpretation is found in the last sentence of Regulation 1.702-1(a)(8)(ii), which reads:

[A]ll relevant items of income or deduction of the partnership must be separately stated for all partners in determining the applicability of Section 270 [now section 183] (relating to "hobby losses") and the recoinputation of tax thereunder for any partner. ${ }^{71}$

The advocates of the partnership position have pointed out that both the gambling gains example in the Senate Report and the "hobby loss" example in the Regulation deal with the separation of items which merely could affect some partner's tax liability differently if separated than if not separated. Separation of the partnership's gambling gams

69. Id.

70. S. REP. No. 1622, 83d Cong., 2d Sess. 377 (1954) (emphasis added).

71. Treas. Reg. $\& 1.702-1$ (a)(8)(ii) (1956). 
or losses will result in a tax liability for some partner different from nonseparation only if some partner has gambling gains or losses in his personal capacity. ${ }^{72}$ Similarly, although it is clear that separation of items relevant to the "hobby loss" deduction could produce a tax liability for some partner different from nonseparation, ${ }^{73}$ it is also clear that in some cases such separation miglit not affect any partner's tax liability. ${ }^{74}$ Therefore, arguing by analogy, it has been contended that prepaid interest and points should also be separated because separation of these items could produce a tax liability for some partner different from nonseparation.

The partnership's argument from the Senate Report and the "hobby loss" example is not persuasive. Reliance upon the Senate Report is unfounded because, whereas it is the timing of the interest deduction rather than its characterization which may affect a partner's tax hability, the Report speaks of items whose character would affect the computation of the partner's tax. ${ }^{75}$ There is a fundamental difference between these two concepts. The character of a partner's distributive share of a partnership item may affect his tax liability if the Code has special requirements as to the handling of items of that character. ${ }^{76}$

72. Gambling losses are deductible only to the extent of gambling gains. INr. REV. CODE OF 1954, $\$ 165$ (d). If a partnership had gambling gains which were separated so that they retained their character on each partner's return, no partner's tax liability would be affected differently by the separation than by nonseparation in the event no partner had gambling losses to offset against his distributive share of the gambling gains. Therefore, separation of gambling gains and losses is not a case in which separation would in every case affect some partner's tax hability differently than nonseparation.

73. "Hobby losses" are only deductible to the extent gross income from the activity exceeds the subsection $183(\mathrm{~b})(1)$ deductions (those allowable without regard to whether or not the activity is engaged in for profit). If a partner had personal "hobby losses" of $\$ 500$ but gross income minus subsection 183(b)(1) deductions of $\$ 1000$, the partner could deduct $\$ 500$. If the partnership had $\$ 5000$ of "hobby losses" and gross mcome minus $183(\mathrm{~b})$ (1) deductions of $\$ 2500$, the partnership would only have a $\$ 2500$ deduction. If the partner's distributive share were $1 / 5$ and the "hobby loss" items were not separated, the partner's total deduction attributable to "hobby losses" would be $\$ 1000$ ( $\$ 500$ personal plus $\$ 500$ distributive share). However, if the "hobby loss" items were separated, the partner would have "hobby losses" of $\$ 1500$ ( $\$ 500$ personal plus $\$ 1000$ distributive share) and gross income minus 183(b)(1) deductions of $\$ 1500$ ( $\$ 1000$ personal and $\$ 500$ distributive share); and his total deduction attributable to "hobby losses" would be $\$ 1500$. Thus, it can be seen that separation of "hobby loss" items could produce a different tax liability for some partner.

74. In cases in which the gross incoine from the activity minus the subsection 183 (b) (1) deductions equals the "hobby losses" for each partner individually and for the partnership, separation of the "hobby loss" items will not produce a different tax liability than nonseparation for any party.

75. S. Rep. No. 1622, 83d Cong., 2d Sess. 377 (1954).

76. An item of gain or loss has a special character if it receives treatment under 
Separation of such items is necessary in order to allow the partners to make accurate returns. However, the character of a partner's distributive share of non-investment interest is irrelevant to the partner's tax liability. ${ }^{77}$ Instead, it is the time at which the deduction for such interest is taken which can affect a partner's tax liability. Since the Report speaks of character and not timing, it is inapplicable to the present problem. The force of the "hobby loss" example as an indication of the correctness of the "could" interpretation is diminished by two other examples given in Regulation 1.702-1(a)(8)(ii). ${ }^{78}$ Both of these examples clearly support the "would" interpretation of the Regulation. In addition, the "could" interpretation of Regulation 1.702-1(a) (8) (ii) renders superfluous Regulation 1.702-1(a)(8)(i) which specifically requires certam "could"70 items to be separated. If those "could" itenis listed in Regulation 1.702-1(a)(8)(i) must be separated by force of Regulation 1.702-1(a) (8) (ii), Regulation 1.702-1(a)(8)(i) would serve little purpose. Therefore, it seems best to conclude that the Coinmissioner meant to separate items the character of which could affect some partner's tax liability through Regulation 1.702-1(a)(8)(i). Regulation 1.702(a)(8)(ii) may then be viewed as a complementary provision which allows the separation of other items only when an affirmative showing has been made that separation of that itein would, in the particular case in question, actually result in a tax hability for

the Code which differs in some respect from the normal treatment of ordinary income items. For example, the characterization of gambling gains and losses as such rather than as mcome derived from an ordinary source can affect one's tax liability since gambling losses may be deducted only to the extent of gambling gains. INT. REV. CoDE of 1954, \& 165(d). Other examples of items having a special character are capital gains and losses, id. $\S \S 1201,1211$, charitable contributions, $i d . \S 170$, and dividends, id. $\$ \S 61(\mathrm{a})(7), 116$.

77. See note 1 supra. Investment interest, however, has a special character which may affect a partner's tax liability because of the limited amount of investment interest which may be deducted in any taxable year. INT. REv. CODE OF 1954, § 163(d).

78. The Regulation requires that "partnership pensions and annuities, interests, rents, dividends, and earned imcome" be separately stated for all partners only in the event some partner would qualify for retirement income credit under section 37 if the items were separated. Treas. Reg. $\$ 1.702-1$ (a)(8)(ii) (1956). Thus, unless a different tax liability would result for some partner from separation than would result froin nonseparation, the item relating to retirement income credit would not be separatcd. Similarly, earned mcome must be separated if some partner is a "bona fide resident of a foreign country who may exclude from his gross income the part of his distributive share which qualifies as earned income as defined in section 911(b)." Id. In this case, separation would produce a tax liability different from that which would be produced by nonseparation for the foreign partner.

79. The term "could item" is used to indicate an item of partnership income which would affect some partner's tax liability differently if separated than if not separated in some cases, but not in every case. Gambling gains and losses and "hobby losses" are examples of "could" items. See notes 72-74 supra and accompanying text. 
some partner different from that which would result in the case of nonseparation.

\section{Recommended Approach}

Both the Internal Revenue Service and the advocates of the partnerships' position have acted on the assumption that the separation of prepaid interest and points must result in the application of the material distortion test at the partner level. ${ }^{80}$ This assumption is, however, unwarranted. Since even separated items are required by paragraph $703(a)(1)^{81}$ to appear on the partnership's return, it would certainly be possible to apply the material distortion test at the partnership level by comparing the separated prepaid interest and points with the partnership's income. Although this does not, in itself, mean that the test should not be applied at the partner level, by rejecting the faulty assumption that the separation of prepaid interest and points must result in the application of the material distortion test at the partner level, another more fundamental analysis of the problem may be adopted which ultimately leads to that result. This analysis centers upon the requirement of subsection $703(b)^{82}$ that elections affecting the coinputation of partnership income shall be determined by the partnership at the partnership level.

The regulations inake it clear that the election of the accounting method to be used with respect to partnership income must be made by the partnership. ${ }^{83}$ Since elections made by the partnership which affect the computation of income are binding on every partner, the distributive share of any item affected by an election required to be made at the partnership level must be treated in the same manner by every partner. ${ }^{84}$ In particular, each partner must report his distributive share of partnership items according to the accounting method

80. See text accompanying note 5 supra.

81. INT. Rev. CoDE of 1954, $\$ 703$ (a) (1) provides in pertinent part, "the items described in section 702(a) shall be separately stated."

82. See note 48 supra and accompanying text.

83. Treas. Reg. $\S 1.703-1$ (b) (1) (1956).

84. In George Rothenberg, 48 T.C. 369 (1967), the court held that if a partnership elects to report capital gains (a separated item) from a sale on the completed-transaction basis, a partner is not entitled to report his distributive share of such gam on the installment method. Accord, John G. Scherf, Jr., 20 T.C. 346 (1953). Revenue Rulimg 66-191, 1966-2 CuM. BuLL. 300, provides that the nonrecognition of gain election under subsection 1033(a) from the involuntary conversion of the partnership's property must be nuade at the partnership level and not by the partners individually with respect to their distributive shares. Similarly, in Frank W. Beilke, I 63,005; P-H Tax. Ct. Mem. (1963), the court held that a partner could not elect to treat his distributive share of gain from timber cutting as capital gain because the election allowed by subsection 631(a) had not been made at the partnership level. 
elected by the partnership..$^{85}$ This is true even if the election of the accounting method affects the tax treatinent of a separated item at the partner level. ${ }^{86}$

Since the election of accounting method with respect to partnership income must be made at the partnership level, every partner must use the method of accounting chosen by the partnership to account for his share of the partnership's prepaid interest. When a material distortion of mcome has been found as a result of a deduction of prepaid interest, the taxpayer whose income has been materially distorted must allocate the deduction over the period of the prepayment. In effect, that taxpayer has been forced to use the accrual method of accounting with respect to the prepaid interest. If prepaid interest were separated out and a partner's incoine were found to have been materially distorted through application of the test at the partner level due to the prepaid interest by his cash-method partnership, his accounting method with respect to that interest would differ from that elected by the partnership, since he would be forced to use the $a c$ crual method. This result would clearly be contrary to section 703(b) in that the accounting method with respect to the partner's share of the partnership income would not have been selected by the partnership at the partnership level. Instead, his accounting method with respect to the prepaid interest would have been determined at the partner level. This accounting method would differ from that selected by the partnership; and possibly from that used by some other partner. In order to avoid this result, it is necessary that the material distortion of income test with respect to prepaid interest be apphied at the partnership level regardless of whether the prepaid interest has been separated.

\section{SUMMARY}

In 1968, the Internal Revenue Service issued Revenue Ruling 68-643 in an attempt to curb the abuse of the tax advantages which flow froin the deductibility of prepaid interest in the year of payment. That Ruling required that the deduction for prepaid interest be taken in the year the interest was earned if immediate deduction would materially distort the taxpayer's income. Since Revenue Ruling 69-188 held that points are to be considered interest, the Service extended Revenue Ruling 68-643's material distortion of incoine test to payinent of points. This extension was unwarranted because of certain differences between prepaid interest and poimts.

85. Josef C. Patchen, 27 T.C. 592,596 n.3 (1956).

86. George Rothenberg, 48 T.C. 369 (1967). 
The question has arisen as to how the material distortion of income test should be applied to prepaid interest and points paid by a partnership. The Service and the partnerships liave disagreed as to whether the test should be applied at the partnership or partner level, the partnerships arguing that the test should always be applied at the partner level. The arguments made by both sides have failed to focus on the basic issue of the problem. The proper analysis centers on the fact that the material distortion test affects the partner's method of accounting for his distributive share of the partnership's deduction for prepaid interest and points. Since the method of accounting for partnership items is an election which must be made by the partnership, the inaterial distortion of income test with respect to prepaid interest and points should be applied at the partnership level. 